Mark A. Graber

\title{
RUNNING CARS, CONSTITUTIONS AND METAPHORS INTO THE GROUND
}

Professor Sanford Levinson frequently analogizes the Constitution of the United States to a vehicle that desperately needs repairs. “[R]elying on the present Constitution.” he writes, “is similar to driving a car with very bad brakes and slick tires." ${ }^{1}$ In his opinion, the Senate, Electoral College, presidential veto, lack of emergency provisions, and Article V are the constitutional equivalents of worn pads and leaky values. No rational person, Levinson asserts, would drive a car so badly flawed. Similarly, he concludes, no rational American should support governance by such an undemocratic constitution.

Much commentary on Our Undemocratic Constitution implicitly challenges the automotive metaphor. The Constitution of the United States, supporters profess, is not really as bad as Levinson would have us believe. What Levinson perceives as outdated parts are, in fact, time tested systems for preserving individual rights and maintaining social stability. Hard to amend constitutional provisions prevent transient majorities from governing in ways that oppress minorities. The presidential veto guarantees that legislation is supported by the one governing official who must run a national campaign. The Electoral College ensures that presidential campaigns are national and do not focus entirely on the needs of densely populated urban areas.

The following pages take a road less traveled. Ancient constitutional institutions in the

\footnotetext{
${ }^{1}$ Sandy Levinson, “Afterword,” 55 Drake Law Review 1009, 1009 (2007).
} 
United States are suffering from severe wear and tear. Nevertheless, American driving habits cast doubt on Levinson's assumption that repair or replacement is the rational response to faulty cars or undemocratic constitutions. Many Americans operate vehicles with bad brakes and slick tires. Few people buy cars on an annual basis, even though next year's model promises improved safety. These decisions to drive a comparatively unsafe car are often grounded in reasons that might justify decisions to forego repairing or replacing an analogously flawed constitution.

Servicing is rational only when persons can afford the costs, trust their mechanic or dealer, and have reason to believe performance will be substantially improved. Replacing or repairing constitutions and cars are not costless. Citizens with other pressing personal or political needs might be best off spending scare resources on food or other social issues. Constitutional and car mechanics are not perfect. Persons may conclude that the persons most likely to perform needed repairs will be more interested in lining their pockets than improving the product. Constitutions and cars may not be susceptible of long term improvement. Good faith brake and constitutional jobs may prove so temporary a fix that persons are better off using the constitutions and cars they have than attempting to obtain newer product lines.

\section{The Metaphor}

The Constitution of the United States is not analogous to an automobile that cannot be driven or driven safely to the local supermarket. Professor Levinson does point out numerous constitutional inefficiencies and is correct to note possible future crises should present 
constitutional practices not be altered. If, however, the standard for constitutional reform is imminent danger of irreparable harm, Our Undemocratic Constitution does not meet the burden of proof. The lack of an emergency powers provision may one day cause catastrophic harm, but that day is unlikely to be today or next week. The Senate may provide small states with unjustifiable benefits, but that harm is not equivalent to the imperiling a transport at sea necessary to justify a prior restraint on free speech.

The better analogy is to my 2002 Toyota Sienna at the time I was writing this essay. The mechanic down the street said the car needed to have a three-hundred dollar brake job. The dealer down the street offered to sell me a car with new and improved brakes for twentythousand dollars. My risk of brake failure in the near future had I ignored these appeals was relatively low. Nevertheless, my mechanic insisted that the brake job would reduce that risk substantially. The dealer claimed that risk would be reduced to near zero if I bought a new car. Both asserted, truthfully, that servicing or a 2009 model, respectively, would improve my gas mileage. I could probably drive the Sienna down to South Carolina, but doing so without repair would be more expensive and risky.

The Constitution on March 16, 2009 was in the same shape as that car. Both had clear inefficiencies. My tires were costing me money at the gas pump. Equal State representation in the Senate was forcing taxpayers in high population states to subsidize projects in low population states. Operating both without serving threatened much greater harms. At some point, although probably not next week, my brakes would fail. At some point, although probably not next week, an election might get thrown in the House of Representatives. Neither my car nor the Constitution was facing an immediate crisis. Nevertheless, maintaining both in their present 
condition had clear costs and risks. The issue is whether those costs and risks justify repair or replacement. $^{2}$

\section{Costs}

Law professors can more easily afford the costs of improving a car or a constitution than ordinary citizens. A three-hundred dollar brake job barely even scratches the family budget. New cars can be purchased annually if the round the world cruise or equivalent is sacrificed. Opportunity costs are minimal. Many service stations now have waiting rooms with internet access for our laptops. For lower-middle class families, the three hundred dollars may be necessary to pay the mortgage. Failing to show up to the office may have severe employment repercussions. Opportunity costs are similarly low when legal scholars teach or write about constitutionalism. Questions of constitutional design should occupy a much larger place in constitutional scholarship and pedagogy, no matter what has to be cut or slimmed to make the needed room. Legal scholarship would be better if law reviews published ten more articles on constitutional design and ten less on almost any subject on which at least twenty-five articles are published annually in the top hundred law reviews. The undergraduate classroom would benefit from discussions of constitutional adequacy, even if that means reducing some time presently devoted to the freedom of speech or equal protection.

Whether President Barack Obama should similarly reallocate his time commitments is

${ }^{2}$ I should note that my mechanic on 3/17 did not advise me to get new tires. The day after repairs were done that car had a flat, which another mechanic blamed on worn parts. 
not as clear. No doubt any President would better serve the country by thinking more seriously about constitutional design than by filling out NCAA tournament brackets or engaging in other symbolic actions. Still, the practical reality is that, if President Obama is to spend serious time thinking about constitutional design, the time is likely to come from activities progressives consider valuable. If President Obama spends more time thinking about constitutional design, he will likely spend less time thinking about the best means for fighting terrorism or ending the recession. Should President Obama be determined to work harder, constitutional design may not be the first beneficiary. Consider the state of a great many inner city schools in the United States or the problems of urban poverty that do not seem very high on the national agenda. A president determined to work extra hours might reasonably decide that the extra time and energy should be spent on these projects, not on whether the Electoral College ought to be scrapped.

The problem of political opportunity costs remains even when a blue ribbon commission or a few federal staffers are assigned to explore constitutional design problems. Given all the commissions and staffers in Washington, DC, one commission or two more staffers devoted to considering possible constitutional reforms seems a reasonable allocation of not-so scarce resources. Nevertheless, difficult choices will have to be made once the blue ribbon commission reports. As political scientists have long known, problems compete for places on the political agenda. ${ }^{3}$ Should constitutional reform gain political traction, less political energy will be spent combating terrorists or drug dealers. Given the reverence with which most Americans hold the Constitution, championing constitutional reform will be politically risky. Much momentum from

${ }^{3}$ See E.E. Schattschneider, The Semisovereign People: A Realist's View of Democracy in America (Dryden Press: Hinsdale, IL, 1975), pp. 60-74. 
the New Deal was squandered when Roosevelt proposed the Court packing plan. ${ }^{4}$ President Obama may be faced with the same painful choice between reducing dramatic inequalities in the United States and proposing constitutional reform (that may, in non-obvious and long term ways, be more effective means for reducing inequality). Given these alternatives, constitutional reform is no more obviously the most rational means for spending scarce political resources than a brake job is for a person whose alternative is buying groceries for the family.

\section{The Mechanic}

Law professors have more reason than ordinary citizens to trust the skills and integrity of those who service cars and constitutions. When our brakes need fixing, we can afford the best shop in town. We know what legally must be done when the dealer sells us a lemon with hidden flaws. Our neighbors may have to rely on mechanics or dealers whose skills and integrity are more suspect. Even when they suspect foul play, legal recourse is often a practical impossibility. Law professors are even better positioned to benefit when a constitution must be altered or replaced, If we do not play the role of mechanic or dealer, those roles are likely to be played by our colleagues, former students, or at least persons more sympathetic to our class interests than average citizens. Those average citizens may have very good reason for thinking that the persons who do the constitutional servicing will have little interest in making the adjustments that improve the political capacities or lot of ordinary Americans.

\footnotetext{
${ }^{4}$ See David Adamany, Legitimacy, Realigning Elections, and the Supreme Court, 1973
} Wisconsin Law Review 790, 839-41, 844-45 (1973). 
Professor Levinson relies heavily on the Jeffersonian claim that advances in the science of politics will enable Americans in the future to fashion better constitutions than Americans in the past. "As [the human mind] becomes more developed, more enlightened, as new discoveries are made, new truths disclosed,” Jefferson believed, “institutions must advance also, and keep pace with the times."5 That spirit animates every page of Our Undemocratic Constitution. Levinson scorns Hamiltonians who exhibit "an utter lack of faith in the democratic potential of our fellow citizens.” "We best honor the framers,” he writes,

(b)y taking the task of creating a republican political order as seriously as they did and being equally willing to learn from what that history of the past 225 years, both at home and abroad, can teach us about how best to achieve and maintain such an order. ${ }^{6}$

The Madisonian response to Jefferson is inadequate. The future fourth president believed that repeated constitutional conventions would "disturb the public tranquility by interesting too strongly the public passions." The Philadelphia drafting convention did "honour to the virtue and intelligence of the people of America," but "experiments” of that sort were "of too ticklish a

${ }^{5}$ Sandy Levinson, Our Undemocratic Constitution: Where the Constitution Goes Wrong (and How We the People can Correct It) (Oxford University Press: New York, 2006), p. ix (quoting Jefferson to Samuel Kercheval, July 12, 1816).

${ }^{6}$ Sandy Levinson, Our Undemocratic Constitution: Where the Constitution Goes Wrong (and How We the People can Correct It) (Oxford University Press: New York, 2006), pp. 175, 16. 
nature to be unnecessarily multiplied."7 Numerous problems exist with this and related claims that the eighteenth century framers, because of the distinctive virtues, wisdom or circumstances, were capable of writing a better constitution than any other generation of Americans. Contemporary constitutional reformers are able to draw on more than 200 years of American practice and the experiences of numerous other polities with democratic constitutions. Contemporary Americans seem at least as virtuous as men who held slaves and questioned whether women had any political capacities. A constitution written in desperate economic times by people desperate to finesse sectional issues might not have been drafted under the most ideal circumstances for framing enduring fundamental laws.

Madison might have better responded to Jefferson, paradoxically, had he taken the framers off their pedestal. Technically proficient car and constitutional mechanics improve performance only when they employ their skills to increase the safety or democratic responsiveness of the instrument in the shop. Both Jefferson and Levinson treat constitutional drafters as faithful artisans, primarily concerned with such constitutional goods as promoting the public interest, preventing self-dealing, and stating national aspirations. On a different view, suggested by a good deal of scholarship in comparative politics, persons writing constitutions are primarily concerned with preserving power against insurgent political forces or seeking some insurance against future falls from power. Professor Ran Hirschl is a particularly forceful proponent of this understanding of constitutional reform. "When their policy preferences have been, or are likely to be, increasingly challenged in majoritarian decision-making arenas,” he

\footnotetext{
${ }^{7}$ Alexander Hamilton, James Madison, and John Jay, The Federalist Papers (Bantam
} Dell: New York, 1982), p. 308. 
writes, “elites that possess disproportionate access to, and influence over, the legal arena may initiate a constitutional entrenchment of rights and judicial review in order to transfer power to supreme courts.”8 Much writing on the American framing suggests the constitutional reform in the United States was a similar exercise in self-dealing. Gordon Wood and Charles Beard, in particular, insist that the persons responsible for the Constitution of the United States were attempting to preserve the power of a republican elite against a democratic tidal wave. ${ }^{9}$

Improvements in the science of automotive repair or politics may have perverse consequences when the service is done by persons primarily interested in self-dealing. An expert at brake jobs will be able both to fix worn pads and hide the creation of a new flaw that will require an even more expensive overhaul. Constitutional experts are better able than ordinary citizens to democratize politics and mask boons for powerful interests. Ignorance may be bliss when constitutions are designed by elites taking insurance against populist uprisings. Some democratic features of contemporary politics, most notably a mass party system that mobilizes ordinary persons, are consequences of founding failures. The framers attempted to foster a more elite politics, but lacked the political knowledge necessary to achieve their intended aristocratic

${ }^{8}$ Ran Hirschl, Toward Juristocracy: The Origins and Consequences of the New Constitutionalism (Harvard University Press: Cambridge, MA, 2004), p. 12. See Tom Ginsburg, Judicial Review in New Democracies: Constitutional Courts in Asian Cases (Cambridge University Press: New York, 2003).

${ }^{9}$ See Gordon S. Wood, The Radicalism of the American Revolution (Knopf: New York, 1991); (Charles A. Beard, An Economic Interpretation of the Constitution of the United States (Macmillan: New York, 1935) 
republic. Should contemporary elites regard constitutional reform as an opportunity to weaken some feature of contemporary democratic politics, they will have far more constitutional experience and expertise to rely on when pursuing that countermajoritarian end.

\section{The Object of Improvement}

Law professors may be more confident than their fellow citizens that cars and constitutions can be improved. The modernist spirit pervades the academy. Through the application of reason and intelligence, scientific faith communities insist, human beings will learn how to make brakes that do not fail, constitutions that do not become obsolete and, perhaps, copy machines that do not jam. ${ }^{10}$ Given the prodigious research that takes place in automotive engineering and constitutional design, contemporary citizens ought to have the capacity to build safer cars and more democratic constitutions than their early twentieth and late eighteenth century ancestors. Others are less impressed. They regard as fads what automotive and political engineers proclaim to be dramatic improvements in safety and elections. In their view, science is far more limited than scientists suspect. We will better promote safety by paying more attention to the road and good government by paying more attention to the needs of other people.

An extraordinarily primitive examination of traffic fatality statistics provides some

\footnotetext{
${ }^{10}$ Ran Hirschl, "The 'Design Sciences' and Constitutional 'Success"' 87 Tex. L.Rev
} (forthcoming in June 2009). 
perspective on modernist assumptions about human capacities and science. ${ }^{11}$ Traffic deaths per mile and population have dropped steadily for the past fifty years. Whether this is a consequence of safer driving or safety engineering is unclear, given substantial drops in alcohol related fatalities. Traffic deaths in the United States remain fairly steady. Between 35,000 and 40,000 persons a year in the United States are killed in automotive accidents. This number seems impervious to change. Technology, the data suggests, has a limited impact on safety in the absence of changes in driving habits. Engineers who consistently design cars that perform better on safety tests do not seem as able to produce vehicles that human beings drive more safely. Persons familiar with this information might reasonably conclude that they will more likely decrease their probability of serious accident by remaining sober and turning off the cell phone than by permitted the mechanic to do a brake job with every oil change or paying twentythousand dollars for a new car with all the latest safety features allegedly in perfect working order.

History casts even more doubt on the human capacity to build long-lasting constitutions. Most constitutional democracies change constitutions with some frequency. ${ }^{12}$ The Netherlands replaced constitutions wholesale in 1972 and 1983, then substantially revised the constitutional text in each succeeding decade. The French sometimes joke that their constitution cannot be

${ }^{11}$ The relevant statistics are from the Fatality Analysis Reporting System, http://wwwfars.nhtsa.dot.gov/Main/index.aspx.

${ }^{12}$ Most of the information in this paragraph comes from Tom Ginsburg, Zachary Elkins, and James Melton, The Endurance of National Constitutions (Cambridge University Press: New York, 2009). 
found in libraries that do not have an extensive periodical collection. Overall, the average constitution lasts about seventeen years. Democratic constitutions do better, but not that much better as to inspire hope that a constitutional convention will not be a generational affair. As important, no good evidence exists that constitutional democracies that adapt new constitutions in non-crisis periods fare better than democracies that continue to work within the established framework. As is the case for automobiles, citizens may be better off working within the political framework with which they have grown comfortable than exchanging old systems for new.

No agreement exists on the elements of a good longstanding constitution. Professor Levinson is right to note that no country adopts what might be described as variations on a theme of the Constitution of the United States. Still, no other constitutional regime presently serves as a model for most new constitutional democracies. Almost every facet of constitutionalism is contestable, from the proper design of the national legislature to the correct rules for amendment. $^{13}$ A recent conference at the University of Texas generated no consensual rules for new constitutional democracies. One paper, examining the history of ambitious design sciences, concluded that the effort to create longstanding constitutions that promoted desirable ends over long period of time was probably a human fantasy akin to time travel. ${ }^{14}$

American constitutional history provides little encouragement for persons who believe that constitutional reform is likely to serve valued purposes. Gordon Wood details how the

${ }^{13}$ See Donald S. Lutz, Principles of Constitutional Design (Cambridge University Press: New York, 2006).

${ }^{14}$ Ran Hirschl, "The 'Design Sciences' and Constitutional 'Success'.” 
aristocratic republic intended by the framers almost immediately disintegrated into a herronvolk democracy. ${ }^{15}$ The Constitution of the United States was designed for the purpose of avoiding party politics, but a strong case can be made that in practice only parties could run the American constitution successfully. Almost every constitutional institution, from the Electoral College to the Senate, almost immediately failed to function as the framers expected. As both Thomas Jefferson and Bruce Ackerman noted, a constitutional revolution took place in 1800 which updated malfunctioning constitutional institutions. ${ }^{16}$ Every framer who lived to see Andrew Jackson regarded the constitution of 1787 to be a miserable failure. ${ }^{17}$

The persons responsible for the Constitution of 1868 performed no better. That regime lasted only eight years. The post-Civil War Constitution was designed to provide protections for persons of color and perhaps southern unionists. The Reconstruction framers, assuming that a Republican coalition would be in charge of Congress and control the federal judiciary for a substantial period of time, relied heavily on vague guarantees of fundamental rights that would provide northern majorities with the flexibility necessary to respond to creative racist outrages in the South. ${ }^{18}$ After the Democrats regained control of the House of Representatives in 1874, racial egalitarians lost the political power necessary to respond constitutionally to most new

${ }^{15}$ Wood, The Radicalism of the American Revolution.

${ }^{16}$ See Bruce Ackerman, The Failure of the Founding Fathers: Jefferson, Marshall and the Rise of Presidential Democracy (Harvard University Press: Cambridge, MA, 2005).

${ }^{17}$ See Wood, The Radicalism of the American Revolution, p. 367.

${ }^{18}$ See William E. Nelson, The Fourteenth Amendment: From Political Principle to Judicial Doctrine (Harvard University Press: Cambridge, MA, 1988). 
atrocities by white supremacists in the former slave states. Presidential enforcement was marred by lack of consistency and funds. Federal justices may have retained some commitment to persons of color, but their moderate path did not provide adequate tools for those persons intent on securing racial equality in the South. Such vague guarantees as "equal protection” that the framers though would empower persons concerned with the fate of former slaves did not provide the clear legal standards that might have constrained racist popular majorities.

Constitutional engineers, the experiences of 1787 and 1868 indicate, overestimate their capacity to predict the future. Constitutional institutions, too often designed to manage crises that never happen, frequently prove unresponsive to and even aggravate the unanticipated threats to regime maintenance that actually occur. Americans have too often resembled the southern farmer who, fearful of possible blizzards, purchased snow tires that tended to skid after the county unexpectedly resurfaced several roads. Levinson’s new constitution may analogously provide Americans will better tools for managing razor close elections between the two major parties, while offering small third parties surprising means for holding politics hostage to their idiosyncratic demands.

Sound car and constitutional improvements may have perverse consequences. People who purchase safer cars may nevertheless increase their risk of accident. More confident in their brakes, they may drive longer, talk more on cell phones, and permit less experienced drivers to take the wheel. Constitutional cure-alls threaten analogous damages. Citizens who believe the Constitution is "a machine that would go of itself"19 may assume after constitutional reform that

19 Michael Kammen, A Machine that Would Go of Itself: The Constitution in American Culture (Vintage Books: New York, 1986). 
they have no further responsibilities for preventing political crises. They may make whatever demands they please of the political system, blithely trusting constitutional processes to generate automatically just outcomes that are consistent with popular preferences and conducive to social stability. Americans who are aware that the inherited regime is defective may have greater capacities to avoid crises than Americans who take for granted that the latest fashion in constitutional institutions guarantees that all political matters are efficiently and fairly resolved.

\section{Constitutional and Human Capacities}

Decisions to service or replace cars or constitutions depend partly on what counts as functioning well. People who rely on their automobile only for transportation keep their vehicles longer than people who want entertainment, comfort, and status as well. Levinson calls for a new constitution that will better democratize American politics and respond to all future crises that can be imagined. Persons will not be moved by his appeals who think good constitutions provide background rules for conducting politics that are not horribly unfair. Constitutions with defective democratic parts need not be repaired or replaced, from this perspective, because fundamental laws serve their primary purpose as long as governing institutions generate reasonable policies that are broadly congruent with popular preferences.

The spirit underlying this antipathy to constitutional revision is not well captured by the slogan, “if it ain’t broke, don’t fix it.” The debate is really over what is constitutionally broken. To the extent constitutions should promote democratization, state equality in the Senate seems analogous to badly worn breaks. To the extent constitutions are expected only to provide 
background rules for conducting politics, state equality in the Senate seems more analogous to a broken stereo system in a car owned by persons who do not especially value being entertained when driving. As long political leaders and citizens follow those background rules, persons with this understanding of constitutional purposes think, the Constitution of the United States is functioning well. By encouraging Americans to tinker with those background rules, Levinson is doing far more damage to American constitutionalism than the democratic imperfections his work highlights.

The frequency with which inherited cars and constitutions should be serviced or replaced also depends on estimations about human capacities. Levinson is confident that contemporary mechanics and citizens have the capacities and interests necessary to improve worn brakes and governing institutions. Sharing Jefferson's faith in the political potential of ordinary people, he has throughout his career insisted that the most important questions of constitutionalism be open to public scrutiny in light of changed circumstances and better knowledge. Lacking Levinson’s optimism or Madison's willingness to trust a republic elite, I suspect that the persons who service my car and constitution will engage in self-dealing and, even if sincere, are unlikely to improve my brakes or my government. Deeply suspicious of the human capacity for politics, I prefer keeping the big questions off the table as much as possible. People are better off learning to drive with bad brakes or compensating for the polarizing tendencies of presidential elections than purchasing new products with unfamiliar, hidden flaws.

Contemporary American politics provides much grist for this pessimism. Democracies may generate a better leadership class than other forms of government. Still, popular majorities during the recent past have proven quite capable of fighting wars on the basis of misinformation, 
adopting ruinous economic policies, and becoming obsessed with such political trivialities as who ought to have a right to love who. A term limited judiciary, a presidency shorn of the veto power, and a Congress apportioned entirely on the basis of population are unlikely to strike at these serious ills of American politics. Worse, Levinson's remedies may foster the populist myth that the central problem with politics in the United States is that unjust institutions are permitting a corrupt elite to suppress the good instincts of the American people.

A constitutional politics that accepts the limited human capacity for politics may nevertheless no longer be feasible. Human beings at the turn of the twenty-first century have unprecedented capacities to kill each other militarily, biologically, and environmentally. Recent trends suggest that politics as presently constituted in the United States (and throughout the world) is incapable of preventing and likely facilitating a catastrophic use of nuclear weapons, a cataclysmic release of deadly viruses and a calamitous change in the earth's climate.

Constitutional orders that operate on the principle that human beings govern themselves poorly will not prevent near or total extinction, even if this assumption about the human capacity for politics is correct. If pessimism is a dead end, then alternatives must promise substantial, immediate improvements in human capacities to think and act politically. Generating a discussion about constitutional design is an excellent place to start. 